\title{
KAPITAŁ SPOŁECZNY ELEMENTEM KONSTYTUTYWNYM BEZPIECZEŃSTWA PUBLICZNEGO
}

\section{Social capital as a constitutive element of public security}

Streszczenie: Szukając nowych rozwiązań dla starych problemów, zwraca się uwage na takie znaczace dla dobrego funkcjonowania wspótczesnego społeczeństwa kwestie jak sieci powiąań międzyludzkich, zaufanie czy normy. Pojęcie kapitału społecznego jest używane już od kilku dekad do opisu i wyjaśniania fenomenu zmian w sferze społeczno-politycznej $i$ gospodarczej, zaistniałych w wyniku transformacji społeczno-ekonomicznej. Odnosi sie ono również do sfery działań obejmujących m.in. budowanie partnerskich i demokratycznych relacji we wspólnotach lokalnych, w których kapitał społeczny stanowi podstawę trwatych sieci społecznego zaangażowania zaufania i wzajemności. Celem prezentowanego artykułu jest próba przedstawienia korzyści wynikających z posiadania przez wspólnote lokalna zasobów kapitału społecznego, jak również wskazanie jego pozytywnego oddziaływania na bezpieczeństwo publiczne.

Słowa kluczowe: kapitał społeczny, zaufanie, bezpieczeństwo publiczne, zasady życia spotecznego

Summary: When looking for new solutions to the old social problems, people pay attention to important issues for the good functioning of today's society, including interpersonal relations, trust, or standards. The term "social capital" has been used for several decades to describe and explain social and political as well as economic changes that took place as a result of the social and economic transformation. It also refers to activities including, among others, the creation of partnerships and democratic relations in local communities in which the social capital forms a basis of permanent networks of social involvement, trust, and mutuality. The purpose of this article is to present the benefits of the local community arising from social capital resources and their positive impact on public safety.

Keywords: social capital, trust, public security, principles of social life

1 Dr hab. Monika Adamczyk, Katolicki Uniwersytet Lubelski Jana Pawła II, e-mail: monika.adamczyk@kul.pl, ORCID: 0000-0002-1331-6026 


\section{Wstęp}

Od połowy lat 90. XX w. zwraca się uwagę na pozytywne oddziaływanie zasobów kapitału społecznego na życie społeczne. Ta bardzo pojemna kategoria pojęciowa, w której mieści się jednocześnie zaufanie, normy wzajemności, współdziałanie i zdolność do organizowania się, jest postrzegana przez analityków jako pożądany i niezbędny składnik ładu społecznego. W literaturze przedmiotu wyróżnia się jego trzy zasadnicze koncepcje. Pierwsza prezentuje go jako „ład przedstawień zbiorowych”, w którym życie społeczne jest oparte na konformizmach grupowych i uregulowane przez tradycyjne wzory. Ład tego typu jest charakterystyczny dla zbiorowości wiejskich i społeczeństw pierwotnych. Druga - ładu monocentrycznego -zakłada, że życie społeczne jest regulowane przez centralnie podejmowane decyzje organizacji czuwającej nad ich przestrzeganiem. Życie społeczne opisywane przez tę koncepcję jest regulowane przez centralne ośrodki decyzyjne i charakteryzuje system biurokracji, w której istnieje hierarchia stanowisk. Trzecią koncepcją ładu społecznego jest ład policentryczny, w którym równowaga społeczna jest osiągnięta dzięki podejmowaniu indywidualnych interakcji, respektujących powszechnie uznane reguły gry i normy współżycia (Mariański 1993: 98). Analiza ta bazuje na określeniu ładu społeczno-moralnego, a ujmując to pojęcie, odwołuje się do idei dobra wspólnego realizowanego przez jednostkę i społeczność (Mariański 1993: 99).

W takim podejściu kapitał społeczny umożliwia jednostkom i mniejszym grupom społecznym przejmowanie odpowiedzialności za własne działania w zmieniającym się społeczeństwie. Taka forma partycypacji społecznej jest bardzo istotnym elementem prawidłowego rozwoju społeczeństwa obywatelskiego, jak również rozwoju gospodarczego. Zrównoważony rozwój społeczny, oparty na zaufaniu i zasadzie wzajemności, jest jednym z konstytutywnych filarów bezpieczeństwa publicznego. Cechą charakterystyczną tak pojmowanego rozwoju jest założenie, że potrzeby obecnego pokolenia mogą być zaspokajane bez pozbawiania tej możliwości przyszłych pokoleń dzięki działaniu opartemu na zasadzie wzajemności i poszanowaniu dobra wspólnego. Rozwój ten odnosi się do aspektów środowiskowych, gospodarczych i społecznych (GUS 2011: 4). Jakie związki zachodzą między kapitałem społecznym, zrównoważonym rozwojem a bezpieczeństwem publicznym? Aby odpowiedzieć na to pytanie, należy najpierw dokonać pewnych uściśleń pojęciowych. 


\section{Pojęcie kapitału społecznego}

Poszukując rozwiązań dla wielu problemów nurtujących współczesne społeczeństwo, nie tylko polskie, uczeni reprezentujący różne dziedziny nauki - m.in. ekonomiści, socjologowie i politolodzy - zwracają uwagę na kwestie, takie jak: sieci powiązań międzyludzkich, zaufanie i normy skłaniające do kooperacji. Pojęcie kapitału społecznego już od kilku dekad służy do opisu i wyjaśniania nowych zjawisk w sferze społeczno-politycznej i ekonomicznej. Termin ten stał się tak pojemny i wieloznaczny, że nowe pokolenia autorów wciąż zastanawiają się nad jego znaczeniem oraz funkcjami na poziomie mikro-, mezo- i makrospołecznym. Czym więc jest kapitał społeczny?

Na poziomie mikrospołecznym jest on przedstawiany jako rodzaj zasobu, jakim dysponuje jednostka. Na poziomie mezospołecznym stanowi zasoby grupowe (np. wspólnot samorządowych czy zakładu pracy), na poziome makrospołecznym zaś określają go czynniki rozwoju społecznego (Przymeński 2005: 22). Pojęcie kapitału społecznego jest różnie konceptualizowane. W niniejszym artykule zostanie rozwinięte w nawiązaniu do teorii Roberta Putnama, Francisa Fukuyamy i Jamesa Colemana, którzy widzieli w kapitale społecznym zasób wiedzy i umiejętności ludzkich, jak również takie - istotne dla rozwoju społeczności - cechy jak: zaufanie, obowiązujące w danej społeczności normy, czy powiązania, które mogą wpływać na zwiększenie sprawności działania tejże społeczności (Lewenstein 2006: 165).

Zaufanie, normy i powiązania ułatwiają koordynowanie działań, przy czym zasadnicze znaczenie mają poziome, a nie pionowe powiązania $\mathrm{w}$ ramach obywatelskiego zaangażowania. Sieci powiązań mające nieformalny, horyzontalny i osobowy charakter dobroczynnie wpływają na gospodarkę. W skali jednostkowej takie silne więzi wspólnotowe mogą przynieść korzyści ekonomiczne, ponieważ w konkretnej wspólnocie, pomiędzy znającymi się osobami łatwiej może nawiązywać się porozumienie i wytwarzać zaufanie, co z ekonomicznego punktu widzenia może pozytywnie wpłynąć na koszty transakcji (Stańczak 2000: 485). Zwraca się jednak uwagę, że nie każde więzi wspólnotowe generują korzyści ekonomiczne. Jeżeli lojalność względem „swoich", np. rodziny, bierze górę nad racjonalnym działaniem, to solidarność grupowa nie sprzyja obdarzaniu zaufaniem „obcych" - członków innych grup społecznych czy innych społeczeństw (Putnam 1995: 269). Tak więc zdolność kapitału społecznego do pobudzania w społeczności gotowości poświęcenia dobra partykularnego - interesu własnej grupy - dla dobra 
społeczeństwa jako całości wiąże się zawsze z konkretnym klasowym społeczeństwem, które - jak podkreślał P. Bourdieu - zawsze przedkłada interes jednych klas czy grup ponad interes innych (Bourdieu 2005: 129-201). W związku z tym działanie wszystkich na rzecz tworzenia kapitału społecznego jako dobra wspólnego może się odbywać, zdaniem J. Colemana, tylko w szczególnych okolicznościach. „Jedynie w warunkach najdalej idącego konsensusu działanie wypływa spontanicznie z jednostkowych celów osób działających. W każdej innej sytuacji działanie spontaniczne nie występuje, bowiem co najmniej jedna osoba życzy sobie czegoś innego" (Coleman 1992: 345).

Z punktu widzenia prowadzonych analiz niezwykle interesującą koncepcją dotyczącą kapitału społecznego jest ta proponowana przez J. Colemana. W swoich analizach łączy on dwie odmienne teorie: socjologiczną teorię relacji społecznych, w której jednostka jest produktem socjalizacji, i drugą - reprezentowaną przez neoliberalnych ekonomistów, widzących jednostkę jako zdeterminowaną własnym interesem i dążeniem do uzyskania maksymalnych korzyści. J. Coleman stawia sobie za cel połączenie obu tych perspektyw - socjologicznej i ekonomicznej - a narzędziem, które ma to mu umożliwić, jest koncepcja kapitału społecznego. Socjolog ten zajmuje się przede wszystkim wzajemnymi powiązaniami pomiędzy rozwojem kapitału ludzkiego i społecznego. To właśnie to założenie jest niezwykle istotne z punktu widzenia analizy związków zachodzących pomiędzy kapitałem społecznym a bezpieczeństwem publicznym. Zdaniem J. Colemana struktura społeczna powstaje w wyniku czynności wykonywanych przez racjonalnie działających aktorów, będących produktem procesu socjalizacji, a działania podejmowane przez tych aktorów są regulowane przez normy, zasady i obowiązki. Obejmuje ona również formalne organizacje, rozproszone wspólnoty i luźne sieci. Struktura ta staje się kapitałem społecznym w momencie, gdy jakiś aktor użyje jej, aby osiągnąć własny cel (Coleman 1988: 95-109).

J. Coleman definiuje kapitał społeczny poprzez funkcje, które on pełni, tzn. przez zjawiska mające jeden wspólny mianownik - wszystkie one posiadają cechy struktury i ułatwiają pewne działania aktorów w ramach tejże struktury. Kapitałem społecznym jest więc zdolność ludzi do współpracy między sobą tak w obrębie grupy, jak i organizacji, która ma na celu realizację wspólnych interesów. Kapitał społeczny ułatwia wspólne działanie, wypełnia przestrzeń społeczną pomiędzy ludźmi, a jego źródłem są interakcje, dzięki którym powiązania i sieci więzi społecznych opierają się na zdrowych 
fundamentach współdziałania. Podobnie jak w przypadku innych form kapitału, także kapitał społeczny służy podnoszeniu efektywności działania, jak również rozwojowi organizacji (Coleman 1990: 308-310).

Jak podkreśla J. Coleman, potrzeba i zdolność ludzi do łączenia się z zamiarem realizacji jakiś wspólnych celów odnosi się nie tylko do celów gospodarczych, lecz także do innych aspektów życia społecznego. „Tak jak inne formy kapitału, kapitał społeczny jest produktywny - umożliwia realizację pewnych celów, których osiągnięcie byłoby niemożliwe w sytuacji jego braku [...]" (Coleman 1988: 95).

\section{Bezpieczeństwo publiczne a społeczność}

Podejmując próbę wykazania wzajemnych związków pomiędzy kapitałem społecznym a bezpieczeństwem publicznym, należy odwołać się, po pierwsze do pojęcia bezpieczeństwa publicznego, a po drugie - do podstawowych zasad życia społecznego, które ściśle wiążą się z pojęciem kapitału społecznego. Bezpieczeństwo publiczne jest wartością konstytucyjną, dla ochrony której możliwe jest ograniczenie korzystania przez obywatela z jego konstytucyjnych wolności i praw, jednak każde z sześciu kategorii interesów szczegółowych wymienionych $w$ art. 31 ust. 3 Konstytucji RP (bezpieczeństwo i porządek publiczny, ochrona środowiska, zdrowie, mienie oraz moralność publiczna) należy definiować w oparciu o aksjologię podstaw Konstytucji, m.in. w nawiązaniu do zasady godności człowieka i zakazu dyskryminacji. Bezpieczeństwo demokratycznego państwa w kontekście wyżej przywołanego artykułu ustawy zasadniczej traktowane jest jako wartość wchodząca w skład interesu publicznego, tj. ogólnego wyznacznika granic wolności i praw jednostki, przy czym interesu publicznego nie należy utożsamiać z interesem państwowym ani przeciwstawiać powinnościom jednostki. Pojęcie „bezpieczeństwo publiczne” wyznacza horyzont najistotniejszych zadań państwa i jego najważniejszą funkcję, jednak nie zostało ono dotychczas w sposób precyzyjny określone w przepisach prawa. W piśmiennictwie zagadnienie to bardzo często jest przedstawiane w sposób fragmentaryczny. Należy też podkreślić, że bezpieczeństwo publiczne nie jest abstrakcyjnym pojęciem nauki prawa administracyjnego (Filaber 2016). Utrzymanie bezpieczeństwa publicznego należy do najstarszych zadań publicznych i wiąże się ściśle z podstawową 
funkcją władzy publicznej. Ze względu na wielowiekową tradycję ta funkcja władzy jest od dawna znana, zakorzeniona w społecznej świadomości i potocznie zrozumiała.

W kontekście prowadzonej analizy warto skupić uwagę na pojęciu społeczności lokalnej. W literaturze przedmiotu wyróżnia się zasadniczo dwa stanowiska odnoszące się do tego terminu. W pierwszym pojęcie społeczności sprowadza się głównie do więzi emocjonalnych, tożsamości zbiorowej, porozumienia społecznego opartego na bezpośrednim kontakcie i osobistej znajomości. Tak rozumiana społeczność jest wspólnotą, której istota wyraża się $\mathrm{w}$ "przeżywaniu i podzielaniu tych samych symboli i wartości stanowiących źródło kulturowej tożsamości grupy; obiektywnych zależnościach i stosunkach, jakie wytwarzają się między ludźmi; respektowaniu zasad porozumienia i współdziałania" (Starosta 2002: 98). Druga orientacja uwzględnia następujące cechy społeczności: wspólne terytorium, wspólny interes społeczny, łączący mieszkańców danego terytorium, a wynikający z użytkowania tego terytorium, interakcje pomiędzy osobami zamieszkującymi dane terytorium i sentyment lokalny (Starosta 2002: 98).

W prezentowanym artykule społeczność/wspólnota lokalna będzie w pewnej mierze łączyć oba podejścia, co oznacza, że będzie rozumiana jako zbiorowość nie tylko zamieszkująca wspólne terytorium, lecz także oparta na trwałym systemie więzi i interakcji społecznych. Charakterystyczną cechą społeczności lokalnej w takim ujęciu jest mocne poczucie przynależności jednostek do grupy i ich identyfikacja z grupą (Olechnicki, Załęcki 1997: 201). Przyjmując, że mocne poczucie przynależności i silna identyfikacja jednostki z grupą będą się wiązać z przyzwoleniem na podejmowanie koniecznych działań gwarantujących niezakłócone i zgodne z wolą obywateli funkcjonowanie instytucji państwowych, samorządowych i społecznych oraz urządzeń publicznych, a także bezpieczeństwo życia, zdrowia i mienia ludności w wyniku przestrzegania akceptowanego przez obywateli porządku prawnego, należy założyć istnienie silnej normy wzajemności i wysokiego poziomu zaufania zgeneralizowanego. To właśnie zaufanie i normy wzajemności, lojalności, uczciwości, rzetelności i odpowiedzialności zwiększają zdolność jednostek do współpracy oraz skłonność do tworzenia trwałych więzi w społeczeństwie. Przyjmują w ten sposób rolę elementów konstytuujących bezpieczeństwo publiczne (Fukuyama 1997: 38). Związek bezpieczeństwa publicznego z zasobami kapitału społecznego wynika więc ze zdolności tego drugiego do rozpowszechniania zaufania w obrębie społeczeństwa lub jego części - zaufania do instytucji, ludzi, 
władzy. F. Fukuyama podkreśla bardzo wyraźnie, że oddziaływanie zaufania uogólnionego podtrzymuje i pomnaża współdziałanie pomiędzy obcy$\mathrm{mi}$, a efektem tego procesu jest powstanie inkluzyjnego kapitału społecznego włączającego obcych do kręgu kooperującej wspólnoty (Fukuyama 2003: 157). W przypadku społeczeństwa polskiego poziom zaufania uogólnionego jest niski. Centrum Badania Opinii Społecznej, które monitoruje tę kwestię od 18 lat, w swoich raportach wyraźnie podkreśla, iż osoby uważające, że większości ludzi można ufać, należą do mniejszości. W raporcie z 2020 r. „Zaufanie społeczne” przekonanie takie deklarował mniej niż co czwarty ankietowany (22\%), a zdecydowana większość respondentów była zdania, że w stosunkach z innymi trzeba być bardzo ostrożnym (76\%) (CBOS 2020). Co ważne, z punktu widzenia rozwoju zasobów kapitału społecznego integracyjnego w ciągu ostatnich ośmiu lat opinie na ten temat praktycznie się nie zmieniły. Pogląd, że większości ludzi można ufać, wyrażany jest nieco rzadziej niż w latach 2008 (26\% wszystkich przebadanych respondentów) i 2010 (również 26\%) CBOS 2008; CBOS 2010), a trochę częściej niż w latach 2002 i 2006 (odpowiednio 19\% i 19\%) (CBOS 2002; CBOS 2006).

Analizując związki pomiędzy zasobami kapitału społecznego a bezpieczeństwem publicznym, należy odwołać się do trzech podstawowych reguł życia społecznego. Pierwszą z nich jest zasada dobra wspólnego, która zobowiązuje członków tak mniejszych, jak i większych zbiorowości do podejmowania wspólnych działań w celu realizacji dobra wspólnego (Coleman 1988: 95). Kapitał społeczny jest zatem czynnikiem ułatwiającym wspólne działanie.

Kolejną zasadą życia społecznego, która koresponduje z pojęciem kapitału społecznego i bezpieczeństwa publicznego, jest zasada solidarności. Zobowiązuje ona jednostki i społeczności do uwzględniania w życiu społecznym tak dobra wspólnego, jak i dobra osoby ludzkiej (Piwowarski 1993: 131). Kapitał społeczny to $z$ kolei wzajemne zobowiązania i oczekiwania, to wspólne normy i sankcje oraz przepływ informacji, a więc wszystko to, co jest konieczne dla podjęcia przez ludzi współpracy w celu realizacji jakiegoś wspólnego dobra (Balcerzak-Paradowska 2004: 95-99). W budowaniu kapitału społecznego szczególne znaczenie pełnią normy i wartości oraz zdolność członków zbiorowości do poświęcenia dobra jednostkowego dla dobra społecznego (Coleman 1990: 306-313). Szczegółowy opis działania opartego o zasoby kapitału społecznego prezentuje J. Coleman, dla którego zobowiązania to kapitał, który wynika ze wzajemnego wsparcia. Gdy jedna osoba pomaga innej, ta druga czuje się zobowiązana do udzielenia pomocy 
pierwszej. Informacja to nic innego, jak kapitał pojawiający się w wyniku kontaktów z innymi ludźmi, czego efektem jest przepływ wiedzy posiadanej przez jedną osobę do innej, która jej nie posiada, a wszystko to w ramach stosunków społecznych, utrzymywanych przez jednostkę. Normy z kolei to część kapitału społecznego, która zawarta jest w samej społeczności i pozwala tej społeczności na efektywne działanie (Coleman 1990: 306-313). Samą normę definiuje J. Coleman jako aprobowaną przez daną społeczność zasadę postępowania określającą, jakie zachowanie w danej sytuacji jest społecznie akceptowane, a jakie nie cieszy się społecznym uznaniem (np. normy zachęcające do nauki, działalności harcerskiej lub zniechęcające do kontaktów z subkulturami czy podejmowania działalności przestępczej) (Coleman 1990: 308-310). Wspólne dobro, silna, zintegrowana wewnętrznie grupa nie powstają szybko. Generowanie kapitału społecznego, tak jak tworzenie każdej innej postaci kapitału, wymaga - zdaniem J. Colemana - czasu i ciągłości działań. Wymienione zasady nie wyczerpują listy wszystkich wskazań, jakie funkcjonują w sferze życia społecznego, a jedynie te, które wprost korespondują z pojęciem kapitału społecznego i bezpieczeństwa publicznego.

Ukazując związek zachodzący pomiędzy kapitałem społecznym, bezpieczeństwem publicznym a regułami życia społecznego, należy podkreślić istnienie sprzężenia zwrotnego pomiędzy tymi trzema elementami. Przestrzeganie zasad życia społecznego, silna integracja z grupą oparta na kluczowych elementach kapitału społecznego, takich jak zaufanie, norma wzajemności, dają podstawę do utrzymania bezpieczeństwa publicznego w jego różnych wymiarach.

\section{Kluczowe obszary zysków z posiadania zasobów kapitału społecznego przez społeczność}

W literaturze przedmiotu wskazuje się, że niezależnie od sposobu konceptualizacji pojęcia kapitału społecznego - jako dobra prywatnego (P. Bourdieu) czy publicznego (J. Coleman, R. Putnam, F. Fukuyama) - można mówić o trzech kluczowych obszarach zysków, jakie ten zasób przynosi, zarówno w sferze ekonomicznej, politycznej, jak i społecznej, w której kapitał społeczny bezpośrednio przyczynia się do rozwiązywania problemów społecznych. Mówiąc o korzyściach "czysto ekonomicznych" wynikających z posiadania przez grupę kapitału społecznego, za przykład 
podaje się wzrost produktywności innych kapitałów - fizycznego, materialnego - czy zaoszczędzenie kosztów transakcji. W społeczności cechującej się wysokim poziomem zaufania zgeneralizowanego, tj. zaufania do innych, czyli "obcych" ludzi, i zaufania do instytucji, obserwuje się zdecydowanie większą skłonność do podejmowania współdziałania i wzajemnej kooperacji. Zaufanie jest zasadniczym składnikiem kapitału społecznego. „Współpraca jest często konieczna - między władzą ustawodawczą a wykonawczą, między robotnikami a kierownikami, między partiami politycznymi, między rządem a prywatnymi grupami, pomiędzy małymi grupami [...] Zaufanie napędza współpracę. Im większy poziom zaufania w obrębie społeczności, tym większe prawdopodobieństwo współpracy. Z kolei współpraca powiększa zaufanie. Ta stała akumulacja społecznego kapitału jest zasadniczym elementem dodatniego sprzężenia zwrotnego" (Putnam 1995: 264-265). Taki stan rzeczy, przy jednoczesnym zaistnieniu innych istotnych czynników, np. dobrej koniunktury gospodarczej kraju, może skutkować zakładaniem nowych przedsiębiorstw czy rozszerzaniem skali transakcji na inne podmioty. Proces ten podnosi więc produktywność innych form kapitału, nie generując przy tym większych kosztów. Oznacza to szeroko rozumianą redukcję kosztów transakcji, czyli kosztów pozyskiwania informacji i zabezpieczania się przed ryzykiem wynikającym z niesłowności partnera $\mathrm{w}$ „biznesie”. W społeczności posiadającej wysoki poziom kapitału społecznego między podmiotami powstaje gęsta sieć kontaktów, co pozwala na kontrolę społeczną i zastosowanie sankcji społecznych wobec nierzetelnego podmiotu gospodarczego. Często taka sankcja jest dużo bardziej skuteczna od wynikającej z przepisów prawa, gdyż normy społeczne, stanowiące źródło wewnętrznej, nieformalnej kontroli społecznej, znoszą potrzebę wprowadzania do sieci sankcji bardziej formalnych i instytucjonalnych (Putnam 1995: 258-264). Normy społeczne są niepisanymi, ale powszechnie zrozumiałymi prawami, które określają, jakie formy zachowania są pożądane, wartościowane i aprobowane w danym kontekście społecznym. Z kolei wspólnota jako mieszanka zaufania, sieci, norm i wzajemności tworzy silną społeczność, w której istnieje nie tylko wspólnie podzielana własność zasobów, lecz także wspólnota wartości i norm.

W literaturze zyski wynikające z posiadania kapitału społecznego w sferze politycznej przedstawiane są jako zagadnienie bardzo złożone. Prezentując je dość ogólnie, można wskazać dwa zasadnicze obszary ich występowania. Pierwszym z nich, niezwykle istotnym z punktu widzenia 
rozważanej problematyki, jest zdolność grup społecznych do organizowania się poza obrębem instytucji państwowych. Drugi obszar to możliwość oddziaływania na instytucje państwowe i samorządowe (Theiss 2006: 121). Należy wyraźnie podkreślić, że obie te płaszczyzny przekładają się na demokratyzację życia społecznego, a tym samym współtworzenie społeczeństwa obywatelskiego ściśle związanego z utrzymaniem bezpieczeństwa publicznego. Zdolność grup społecznych do samoorganizowania się poza obrębem instytucji samorządowych i rządowych wynika ze wspólnie wyznawanych wartości i wspólnoty celu, dla którego powstają te organizacje. Chęć organizowania się ma swoje źródło również w tym, że ludzie tworzący organizacje uczestniczą $w$ różnego rodzaju sieciach. Uczestnictwo $\mathrm{w}$ sieciach $\mathrm{i}$ istnienie mniej lub bardziej gęstych, przeplatających się powiązań pomiędzy jednostkami i grupami jest zaś kluczową sprawą w tworzeniu kapitału społecznego. Jednostki wchodzą we wzajemne relacje poprzez tworzenie dobrowolnych związków. Kapitał społeczny nie może być budowany poprzez działania podejmowane jedynie dla własnej korzyści. Ta właściwość uzależnia go od zdolności jednostek do działania w zbiorowościach i od umiejętności nawiązywania i podtrzymywania nowych powiązań, kontaktów, a docelowo sieci.

Oddziaływanie na instytucje państwowe i samorządowe podlega regule mówiącej, że kapitał społeczny wzmaga proaktywność. Rozwój kapitału społecznego wymaga chętnego i aktywnego angażowania się ludzi we wspólne uczestnictwo $\mathrm{w}$ działaniu w obrębie wspólnoty. Ludzie proaktywni to obywatele organizacji współdziałający ze sobą w formalnych i nieformalnych strukturach, tworzący w ten sposób otoczenie społeczne, które może podnosić efektywność instytucji państwowych. Nowoczesne koncepcje rozwoju lokalnego promują podejście, zgodnie z którym jednym z podstawowych zasobów służących rozwojowi lokalnemu są zinstytucjonalizowane sieci społeczne tworzone wokół lokalnych organizacji (zwłaszcza pozarządowych), grup społecznych i mieszkańców (Lewenstein 2006: 167). To dzięki nim zwiększa się bowiem zdolność do komunikacji zbiorowej, a także zdolność do samoorganizacji wspólnot lokalnych, m.in. w celu formułowania postulatów wobec władz, tworzenia grup nacisku i kontroli oraz wspierania służb państwowych w wykonywaniu zadań w sferach bardziej nieformalnych, np. opieki hospicyjnej. Twierdzenia te pozostają w zgodzie z poglądami R. Putnama, iż o wiele lepsze konsekwencje dla obywatelskiej współpracy mają poziome zinstytucjonalizowane sieci powiązań społecznych. Definiuje on kapitał społeczny jako zestaw 
nieformalnych wartości i norm etycznych wspólnych dla członków określonej grupy i umożliwiających im skuteczne współdziałanie.

\section{Wnioski}

Korzyści wynikające z posiadania przez wspólnotę kapitału społecznego wykraczają zdecydowanie poza sfere gospodarczą i polityczną kształtującą dobrze funkcjonujące społeczeństwo obywatelskie (Popławski 2008: 319). Kapitał społeczny wpływa na jakość życia społeczności lokalnych oraz pojedynczych osób, przyczyniając się do rozwiązywania problemów społecznych i indywidualnych życiowych sytuacji kryzysowych. Jak to się dzieje? W oparciu o określone wzory zachowań, wzajemne zaufanie, normę wzajemności wpływającą na skłonność do współpracy oraz na sferę pracy i zatrudnienia powstaje sieć kontaktów dostępnych jednostce, szczególnie tych słabych kontaktów w sensie częstotliwości i podstawy więzi. Kapitał społeczny oznacza bowiem działanie jednych osób dla korzyści innych, nawet kosztem interesu własnego, zakładające jednak oczekiwanie, że to działanie zostanie $\mathrm{w}$ przyszłości odwzajemnione.

Obecność kapitału społecznego sprzyja wychodzeniu ludzi ze społecznej izolacji i podejmowaniu przez nich skutecznych działań motywujących instytucje do efektywniejszego rozwiązywania problemów lokalnych społeczeństwa. Bezpieczeństwo publiczne w rozumieniu prezentowanym w tej analizie może być utrzymane dzięki kulturze zaufania i kooperacji, które stanowią elementy konstytutywne kapitału społecznego. To właśnie one sprzyjają wychowaniu bardziej świadomych swej społecznej roli obywateli, dzięki czemu sprawniej działają instytucje publiczne odpowiedzialne za rozwój gospodarczy regionów i państw (Field 2003: 32). Główną funkcją kapitału społecznego jest obniżenie poziomu niepewności w życiu społecznym, gdyż otwiera on możliwość zwiększenia aktywności gospodarczej poszczególnych podmiotów oraz ograniczenia części kosztów transakcyjnych (Marzec 2009: 110). Niezależnie więc od tego, czy kapitał społeczny traktujemy jako cechę małych grup społecznych, czy przeciwnie - atrybut większych układów społecznych, zaufanie rozpowszechnione na różnych płaszczyznach życia gwarantuje współpracę, która może przynieść korzyści i buduje dobro zbiorowe, poczucie bezpieczeństwa i odpowiedzialności za własne losy. Przemiany, jakie zachodzą 
we współczesnych społeczeństwach, dowodzą konieczności badania mechanizmów powstawania kapitału społecznego i uświadamiania istotnych korzyści z jego posiadania.

\section{Nota bibliograficzna}

W artykule zostały wykorzystane materiały zawarte we wcześniejszych pracach Autorki:

Adamczyk, M. (2017), Zasoby kapitału społecznego a wzrost bezpieczeństwa publicznego, [w:] U. Soler, M.L. Górka (red.), Globalne i lokalne wyzwania w obszarze wspótczesnej polityki bezpieczeństwa, (Poznań: Media-Expo Poznań): 197-211.

Adamczyk, M. (2013), Wprowadzenie do teorii kapitału społecznego, (Lublin: Wydawnictwo KUL).

Adamczyk, M. (2012), Kapitat społeczny szansa na budowanie partnerskich relacji we wspólnotach lokalnych, [w:] T. Zbyrda, B. Krempa (red.), Pomoc jako zachowanie prospołeczne, (Lublin: Wydawnictwo KUL): 489-500.

Adamczyk, M. (2011), Kapitał społeczny a sieci relacji we wspólnotach lokalnych, [w:] S. Partycki (red.), Społeczeństwo sieci. Gospodarka sieciowa w Europie Środkowej i Wschodniej, t. 1, (Lublin: Wydawnictwo KUL): 316-326.

\section{Bibliografia}

Bourdieu, P. (2005), Dystynkcja. Społeczna krytyka władzy sadzenia, (Warszawa: Wydawnictwo Naukowe SCHOLAR).

Balcerzak-Paradowska, B. (2004), Rodzina i polityka rodzinna na przełomie wieków. Przemiany, zagrożenia, potrzeba działań, (Warszawa: Wydawnictwo Instytutu Pracy i Spraw Socjalnych).

CBOS (2002), Jacy jesteśmy? Zaufanie Polaków do ludzi i instytucji publicznych oraz gotowość do wspótpracy, Komunikat z badań BS/40/2002, https://www.cbos.pl/ SPISKOM.POL/2002/K_040_02.PDF (7.09.2021).

CBOS (2006), Zaufanie w sferze prywatnej i publicznej a społeczeństwo obywatelskie, Komunikat z badań BS/24/2006, https://www.cbos.pl/SPISKOM.POL/ 2006/K_024_06.PDF (7.09.2021). 
CBOS (2008), Zaufanie społeczne w latach 2002-2008, Komunikat z badań BS/30/2008, https://www.cbos.pl/SPISKOM.POL/2008/K_030_08.PDF (7.09.2021).

CBOS (2010), Zaufanie społeczne, Komunikat z badań BS/29/2010, https://www. cbos.pl/SPISKOM.POL/2010/K_029_10.PDF (7.09.2021).

CBOS (2020), Zaufanie społeczne, Komunikat z badań nr 43, https:/ / www.cbos.pl/ SPISKOM.POL/2020/K_043_20.PDF (7.09.2021).

Coleman, J. (1988), Social Capital in the Creation of Human Capital, "American Journal of Sociology", 94: S95-S122.

Coleman, J. (1990), Foundations of Social Theory, (Cambridge: Harvard University Press).

Coleman, J. (1992), Podstawy teorii decyzji zbiorowych, [w:] M. Kempny, J. Szmatka (red.), Wspótczesne teorie wymiany społecznej, (Warszawa: Wydawnictwo Naukowe PWN): 346-362.

Field, J. (2003) Social Capital, (London-New York: Routledge).

Filaber, J. (2009), Pojęcie bezpieczeństwa publicznego w prawie administracyjnym (wybrane uwagi), „Wrocławskie Studia Erazmiańskie”, 3, http:/ / www.repozytorium. uni.wroc.pl/Content/34474/016.pdf (12.02.2021).

Fukuyama, F. (2003), Kapitat społeczny, [w:] L.E. Harrison, S.P. Huntington (red.), Kultura ma znaczenie. Jak wartości wpływaja na rozwój społeczeństw, (Poznań: Wydawnictwo Zysk i S-ka): 169-187.

Fukuyama, F. (1997), Zaufanie. Kapitat społeczny a droga do dobrobytu, (WarszawaWrocław: Wydawnictwo Naukowe PWN).

GUS (2011), Wskaźniki zrównoważonego rozwoju Polski, Katowice, http://stat.gov. pl/obszary-tematyczne/inne-opracowania/inne-opracowania-zbiorcze/ wskazniki-zrownowazonego-rozwoju-polski,5,1.html (1.03.2021).

Kitler, W. (2011), Bezpieczeństwo narodowe RP. Podstawowe kategorie, uwarunkowania, system, (Warszawa: Wydawnictwo Akademii Sztuki Wojennej).

Konstytucja Rzeczypospolitej Polskiej z dnia 2 kwietnia 1997 r., Dz.U. 1997 nr 78, poz. 483 z późn. zm.

Lewenstein, B. (2006), Społeczeństwo rodzin czy obywateli - kapitał społeczny Polaków okresu transformacji, „Societas/Communitas”, 1: 163-196.

Mariański, J. (1993), Religia i Kościół w społeczeństwie pluralistycznym. Polska lat dziewięćdziesiątych, (Lublin: Redakcja Wydawnictw KUL).

Mariański, J. ( 2007), Społeczeństwo ponowoczesne i jego dylematy moralne, [w:] S. Partycki (red.), Nowoczesność, ponowoczesność. Społeczeństwo obywatelskie w Europie Środkowej i Wschodniej, t. 1, (Lublin: Wydawnictwo KUL): 24-35.

Marzec, M. (2009), Zaufanie do podmiotów sfery publicznej w budowaniu kapitatu społecznego wspólnoty lokalnej, "Organizacja i Kierowanie”, 3: 109-123.

Nowak, E. (2007), Zarządzanie kryzysowe w sytuacjach zagrożeń niemilitarnych, (Warszawa: Akademia Obrony Narodowej).

Olechnicki, K., P. Załęcki (1997), Słownik socjologiczny, (Toruń: Graffiti BC). 
Piwowarski, W. (1993), Słownik Katolickiej Nauki Społecznej, (Warszawa: PAX-Palabra).

Popławski, T. (2008), Kapitat społeczno-kulturowy wsi podlaskiej, [w:] J. Kurczewska (red.), Oblicza lokalności. Ku nowym formom życia lokalnego, (Warszawa: Wydawnictwo IFiS PAN): 319-331.

Przymeński, A. (2005), Kapitał społeczny a społeczeństwo, [w:] H. Januszek (red.), Kapitał społeczny we wspólnotach, (Poznań: Wydawnictwo Akademii Ekonomicznej w Poznaniu): 22-30.

Putnam, R. (1995), Demokracja w działaniu. Tradycje obywatelskie we współczesnych Włoszech, (Kraków: Znak).

Stańczak, Z.J. (2000), Kapitał społeczny a społeczna gospodarka rynkowa, [w:] S. Partycki (red.), Społeczna gospodarka rynkowa w Polsce. Model a rzeczywistość. III Międzynarodowa Konferencja Socjologiczna, Natęczów 15-17 czerwca 2000, (Lublin: Wydawnictwo UMCS): 483-491.

Starosta, P. (2002), Społeczność lokalna, [w:] K.W. Friske (red.), Encyklopedia socjologii, t. 4, (Warszawa: Oficyna Naukowa): 97-108.

Theiss, M. (2006), Kapitat społeczny środowiska lokalnego - pojęcia i problemy, [w:] W. Theiss, B. Skrzypek (red.), Edukacja i animacja społeczna w środowisku lokalnym, (Warszawa: Centrum Wspierania Aktywności Lokalnej CAL): 109-126. 